\title{
Análise cinemática e metamórfica das rochas da Formação Xambioá na porção norte do Cinturão Araguaia
}

\section{Gabriel Bueno Fagundes de Freitas*, Vinícius Tieppo Meira}

\section{Resumo}

O Orógeno Araguaia representa parte da história de amalgamação e configuração do supercontinente Gondwana no final do Neoproterozoico. As sequências metassedimentares que compõem o orógeno registram a história tectônica de desenvolvimento e formação dessa unidade geotectônica. O presente estudo evidencia que as rochas da Formação Xambioá na área estudada incluem majoritariamente xistos micáceos, xistos quartzosos, xistos grafitosos e rochas calciossilicáticas, e rochas metabásicas ocorrem subordinadas. Estas rochas apresentam estruturas planares em três estágios: foliação $S_{n-1}$, registrada como dobras intrafoliais; foliação principal $S_{n}$, definida por xistosidade e bandamento metamórfico; e foliação $S_{n+1}$, definida como clivagem de crenulação e clivagem espaçada. Estudos petrográficos evidenciaram que tanto as rochas metapelíticas quanto as rochas metabásicas atingiram condições de fácies xisto verde alto a anfibolito médio, com características báricas de metamorfismo do tipo Barrowiano.

\section{Palavras-chave:}

\section{Gondwana, Evolução tectono-metamórfica, Orógeno Araguaia}

\section{Introdução}

O Orógeno Araguaia está inserido na história de amalgamação e configuração do supercontinente Gondwana no final do Neoproterozoico. O Supergrupo Baixo Araguaia abriga as rochas metassedimentares deste orógeno (Abreu, 1978), sendo subdividido nos grupos Estrondo e Tocantins. O Grupo Estrondo aflora na região leste do orógeno e compreende, da base para o topo, as formações Morro do Campo e Xambioá. A região de estudo, nas proximidades do município de Xambioá-TO, com destaque às áreas da Cachoeira de São Miguel e Cachoeira de Santa Isabel no leito do rio Araguaia, compreende rochas do Grupo Estrondo (Moura et al., 2008). Considerando que estudos tectonometamórficos são escassos no Orógeno Araguaia, o presente projeto buscou estudar em detalhe duas seções transversais da Formação Xambioá ao longo do rio Araguaia, nos municípios de Xambioá-TO, São Geraldo do Araguaia-PA e Santa Isabel do Araguaia-PA.

\section{Resultados e Discussão}

Com base no estudo dos dados estruturais da área estudada, foram observadas três foliações, denominadas $S_{n-1}, S_{n}$ e $S_{n+1}$. $S_{n-1}$ ocorre registrada como dobras intrafoliais apertadas a isoclinais e foliações internas em porfiroblastos de granada. $S_{n}$ compõe a foliação principal da área e é definida por xistosidade (leitos micáceos contínuos) e bandamento metamórfico, relacionada a proeminente lineação mineral e de estiramento $\left(L_{n}\right)$. $S_{n+1}$ é definida por clivagem de crenulação e clivagem espaçada. Dobras $F_{n}$ (dobras intrafoliais) e $F_{n+1}$ (dobras abertas a fechadas assimétricas e crenulação) são observadas em escalas meso- e microscópicas.

As rochas descritas petrograficamente incluem xistos micáceos, xistos quartzosos, xistos grafitosos e rochas calciossilicáticas, além de rochas metabásicas. As principais paragêneses encontradas nos xistos da Formação Xambioá incluem: (i) quartzo + plagioclásio + muscovita + clorita; (ii) quartzo + plagioclásio + biotita + muscovita + clorita (iii) quartzo + plagioclásio + biotita + muscovita + granada \pm clorita; (iv) e quartzo + biotita + muscovita + cianita + estaurolita + granada \pm plagioclásio. Os anfibolitos, por sua vez, apresentam paragênese hornblenda + plagioclásio + granada \pm epidoto/clinozoisita \pm tremolita/actinolita. Essas descrições indicam que as rochas da região atingiram condições de fácies xisto verde alto a anfibolito médio.

\section{Conclusão}

A evolução tectono-metamórfica da área estudada vincula-se à tectônica compressiva de inversão da bacia Araguaia. As rochas estudadas atingiram condições metamórficas de fácies xisto verde alto a anfibolito médio em regime bárico compatível com metamorfismo do tipo Barrowiano. A fase metamórfica principal relaciona-se com movimentação de massa principal de topo para noroeste. Dobras $F_{n+1}$, que variam de abertas a fechadas e assimétricas, indicam vergência para oeste/oestenoroeste e sugerem continuidade da deformação em condições metamórficas de fácies xisto verde inferior.

\section{Agradecimentos}

Os autores agradecem ao CNPq e à FAPESP pela bolsa de iniciação científica e pelo financiamento do projeto temático intitulado "O Sistema Terra e a Evolução da Vida durante o Neoproterozoico", o qual o presente trabalho está vinculado.

\footnotetext{
Abreu FD. O Supergrupo Baixo Araguaia. In SBG, Congresso Brasileiro de Geologia 1978 (Vol. 30, pp. 539-545).

Moura CA, Pinheiro BL, Nogueira AC, Gorayeb PS, Galarza MA. Sedimentary provenance and palaeoenvironment of the Baixo Araguaia Supergroup: constraints on the palaeogeographical evolution of the Araguaia Belt and assembly of West Gondwana. Geological Society, London, Special Publications. 2008 Jan 1;294(1):173-96.
} 